\title{
The Effect of Pre-Task and Online Planning Conditions on Complexity, Accuracy, and Fluency on EFL Learners' Written Production
}

\author{
Maedeh Ghavamnia, Mansoor Tavakoli and Masood Esteki \\ University of Isfahan, Iran
}

Received: 26 September 2011 / Accepted: 10 March 2012

ISSN: $1697-7467$

\begin{abstract}
The purpose of this study was to investigate how pre-task and online planning could have impact on the three dimensions of language production. Language performance and proficiency are believed to be multi-dimensional in nature, and that their principal dimensions can be examined through the notions of complexity, accuracy and fluency (Skehan, 1998; Ellis, 2008; Ellis \&Barkhuizen, 2005). To conduct the study, forty intermediate EFL learners from a language center in Iran were selected to participate in this study. They were homogenized in terms of gender, age, nationality, L1, and English proficiency. They were randomly assigned to either the pre-planning or the online planning conditions and were required to complete a written narrative based on a series of pictures. Ten of the participants in the pre-task planning condition were randomly selected to participate in a retrospective interview following the task to see what they did during the 10 minute planning time. Independent samples t-tests were run in order to see if any significant difference existed in the writing performance of the participants under the two planning conditions in relation to complexity, accuracy, and fluency. The findings of this study showed that the pre-task planning group produced more complex and fluent writings, whereas the online planning group produced more error free clauses indicating a more accurate writing performance.

Keywords: Online planning, pre-task planning, complexity, accuracy, fluency.
\end{abstract}

El efecto de la pre-tarea y la planificación en línea en la complejidad, precisión y fluidez en la producción escrita de estudiantes de inglés como lengua extranjera

RESUMEN: El propósito de este studio fue investigar cómo la pre-tarea y la planificación en línea pueden tener un impacto en las tres dimensiones de la producción del lenguaje. La actuación lingüística y la competencia se cree que son multi-dimensionales en la naturaleza, y que sus principales dimensiones pueden ser examinadas a través de las nociones de complejidad, precisión y fluidez (Skehan, 1998; Ellis, 2008; Ellis y Barkhuizen, 2005). Para realizar el estudio, cuarenta estudiantes de ingles como lengua extranjera de nivel intermedio de un centro de idiomas en Irán fueron seleccionados para participar en este estudio. Que se homogeneizaron en términos de género, edad, nacionalidad, L1, y el dominio de inglés. Los participantes fueron asignados al azar a la pre-planificación o las condiciones de planificación en línea y se les pidió que completaran un relato escrito sobre la base de una serie de imágenes. Diez de los participantes en la condición de pre-planificación de tareas fueron seleccionados aleatoriamente para participar en una entrevista retrospectiva después de la tarea para ver lo que hicieron durante el tiempo de planificación de 10 minutos. Muestras independientes de t-tests se llevaron 


\begin{abstract}
a cabo con el fin de ver si existía alguna diferencia significativa en el rendimiento de escritura de los participantes en las dos condiciones de planificación en relación con la complejidad, precisión y fluidez. Los resultados de este estudio mostraron que el grupo de planificación previa a la tarea produjo escritos más complejos y de forma má fluida, mientras que el grupo de planificación en línea produjo más frases sin errores lo que indica un rendimiento de escritura más preciso.
\end{abstract}

Palabras clave: la planificación en línea, pre-tarea de planificación, la complejidad, precisión, fluidez.

\title{
1. INTRODUCTION
}

One way of accounting for language performance is by examining the complexity, accuracy, and fluency of the language produced. According to Skehan (2009), successful performance in task-based contexts include: complexity, defined as more advanced language, accuracy, in which the performer tries to make as few errors as possible, and fluency, the rate of speech production. Since speaking and writing are seen as complex and multi-faceted phenomenon involving a series of interrelated stages, attention to one aspect of production is likely to be at the expense of the other. Depending on the situation, an L2 learner's attention might be focused on one of the three aspects of performance while jeopardizing the other two. For example, L2 learners who are more concerned with the correctness of what is said might not pay much attention to how something is said or vice versa. Therefore L2 learners, especially those at lower levels of proficiency, find it difficult to attend to meaning and form at the same time. L2 learners' problems in production may be lessened if they are given time to plan before they produce an L2 utterance or composition. When learners are given the opportunity to plan the linguistic and propositional content of an upcoming task, they can make up for the drawbacks in their language production and as a result the quality of the linguistic output is improved. In relation to providing learners with opportunities for planning, a number of studies have investigated the impact of planning on language production over the last past decade (e.g. Ellis, 1987; Mehnert, 1998; Ortega, 1999).

In contrast to the number of studies that have investigated the effects of planning on speaking production (Ahmadian \& Tavakoli, 2011), few studies have undertaken the effects of different types of planning on written narratives. As thus, this study was designed to examine the effects of pre-task planning and online planning on EFL learners' written narratives. Further, the study sought to investigate through a follow up interview, what the participants in the pre-task planning condition did prior to starting the writing task.

\section{Literature REVIEW}

Planning has attracted considerable attention and has been shown to produce relatively consistent effects on L2 production (Ellis, 2005). Studies (e.g. Foster \& Skehan, 1996) have shown that when learners are provided with an opportunity to plan a task before executing it, the language they produce is more fluent and more complex than when no planning is possible (Ellis, 2005). As a result complexity, accuracy, and fluency (CAF) have turned into major research variables in the field of applied linguistics. 
Skehan (1996) has distinguished these three aspects of linguistic performance; Fluency concerns the learner's capacity to produce language in real time without undue pausing and hesitation (Skehan, 1996, 22). Speech rate, length of run, and pause length are only a few ways of measuring fluency. Complexity concerns the elaborate or ambition of the language that is produced (Skehan, 1996, 22). Complexity can be measured based on subordination or lexical complexity. Accuracy is the extent to which the language produced is correct. In other words, it is the amount of separation from a norm. Bearing this in mind that L2 learners usually find it difficult to pay simultaneous attention to form and meaning, it is perfectly understandable that the study of the potential benefits of planning in language production have become a relevant area of concern in language learning studies.

Researchers have distinguished two major types of planning pre-task planning and within-task planning (online planning). These are distinguished based on when the planning takes place either before the task itself or during the performance of the task (Ellis, 2005). Pre-task planning is further divided into rehearsal and strategic planning. According to Ellis (2005):

Rehearsal entails providing learners with an opportunity to perform the task before the 'main performance'. In other words, it involves task repetition with the first performance of the task viewed as a preparation for a subsequent performance. Strategic planning entails learners preparing to perform the task by considering the content they will need to encode and how to express this content. In pre-task planning, the learners have access to the actual task materials. Within-task planning can be differentiated according to the extent to which the task performance is pressured or unpressured. This can be achieved most easily by manipulating the time made available to the learners for the on-line planning of what to say/write in a task performance. When this is unpressured the participants have the opportunity to conceptualize, formulate and articulate their messages with some care.

Moreover, Yuan and Ellis (2003) define online planning as 'the process by which speakers attend carefully to the formulation stage during speech planning and engage in pre-production and post-production monitoring of their speech acts'. In the case of pre-task planning, learners plan propositional content and isolated chunks of language to encode it. As the name suggests, online planning takes place during performance of a task, whereas pre-task planning examines how planning prior to performance influences production.

A number of studies have investigated the effects of planning on L2 learners' oral performance. Research lends general support to the claim that planning in advance impacts positively on language production, mostly fluency and complexity (Ortega, 1999). Studies by Crookes (1989), Foster and Skehan (1996), Skehan and Foster (1997), Wendel (1997) and Mehnert (1998) report that pre-task planning results in increased fluency. In addition, pre-task planning has a positive effect on complexity, in that more complex language is produced by planners than non-planners (Ellis, 2004). Foster and Skehan (1996) found that detailed planners used significantly more subordination than undetailed planners. Wigglesworth (1997) reports that one-minute of planning time only led to more complex language use in the high proficient learners on the difficult task. Yuan and Ellis (2003) found that pre-task planning had a positive effect on complexity. As thus, it has been found that pre-task planning has a 
positive effect on fluency and complexity. When it comes to accuracy, however, the effects of strategic planning are less certain.

Similar to the research in speaking contexts, the few planning studies in L2 writing contexts that have been conducted also employed different variables in terms of planning conditions, task types, and the aspects of L2 learners' writing performances that were analyzed (Kroll, 1990). What can be interpreted from the research on written narratives to date is that advanced planning time itself does not seem to have much effect on L2 learners' output in writing. This is different from the research on speaking, which generally shows that learners' oral production may improve by simply allowing them time to plan before speaking. Since writing processes can involve longer time for both pre-task and online planning than speaking processes, the effects of extra time for pre-task planning can easily blur in the sequence of time for composing. Learners in these studies may also have revised their produced text and corrected their mistakes while writing, and thus the effects of pre-task planning on accuracy may not be evident in their writing performance.

Up to now, a number of studies have examined planning and its effect on L2 performance. In sum, the studies have found that giving learners time to plan prior to executing a task (speech production) resulted in more fluency and complexity. However, the results for accuracy are not consistent in different studies. According to Ellis and Yuan (2004) 'pre-task planning aids fluency and complexity but not necessarily accuracy in L2 learners' oral narratives'.

Despite the considerable amount of theoretical and empirical evidence that supports the importance of giving the learners the opportunity to plan in oral performance, the role that pre-task and online planning play in written production remains unclear (Ellis \& Yuan, 2004). As thus, additional examination of planning conditions in the writing performance of EFL learners is needed. Accordingly, this study tries to catch up to studies conducted on speech production by investigating the effects of planning on written narratives. The present study attempted to explore if any significant difference existed among the written narratives of the EFL learners in the pre-task and online planning conditions in relation to CAF. In addition, since few studies have examined how students manage their time under the pretask planning condition, this study aimed to cover this gap by conducting a retrospective interview with the EFL learners after the completion of their written narratives.

\section{RESEARCH QUESTIONS / HYPOTHESES}

This study was designed to answer the following research questions:

1. Is there a significant difference in the accuracy of EFL learners' writings in the pretask and online planning conditions?

According to the literature, the online planning condition will result in more accurate performance

2. Is there a significant difference in the fluency of EFL learners' writings in the pretask and online planning conditions?

According to the literature, the pre-task planning condition will result in greater fluency. 
3. Is there a significant difference in the complexity of EFL learners' writings in the pre-task and online planning conditions?

According to the literature, the pre-task planning condition will result in greater complexity.

4. How did the EFL learners manage their planning time in the pre-task planning condition?

\section{4. Меthod}

This study was a single-factor, between-subjects design with two levels of planning condition (pre-task planning and online planning). The forty participants were randomly assigned to one of the two groups. Each group produced a written narrative elicited by means of a set of related pictures in one of the two conditions. The participants' textual products were then analyzed in terms of complexity, accuracy, and fluency.

\subsection{Participants}

The participants under study included forty EFL learners who were enrolled in a language center in Isfahan. The students met 3 times a week for one and a half hour for a total number of 25 sessions. The book they worked on the Top Notch book level 3A. They were all male, between 20 and 24 years old. All were native speakers of Persian, learning English as their second language. None of the participants had been to any English speaking country prior to the study. The participants in this study had learned their English in an instructed setting.

The rationale behind the selection of the participants was their teacher's judgment based on previous writing activities completed in class. From among the 70 students enrolled in the intermediate courses, forty were recognized by the instructors as having an intermediate writing ability. These were students who had received $65-75 \%$ on the mid-term exam. According to the language center writing scores ranging between $65-75 \%$ indicates an intermediate writing ability. The mid-term and final exam at the language institute consisted of structure, vocabulary, reading, and writing sections. The writing section which was our concern consisted of 3 topics given to students. From among the topics two were chosen by the students to write about. The criterion for marking the EFL learners' writings was uniform among all instructors. Next, the students were divided randomly into two groups; each planning condition consisting of twenty EFL learners. The participants were considered homogeneous in terms of their gender, age range, first language (L1), nationality, and writing ability which was evaluated based on the instructors' judgment and their mid-term writing scores.

\subsection{Task}

In this study the participants in both pre-task and online planning groups were required to write a picture compositions based on a picture story. They were supposed to make interpretations about what would happen throughout the picture story. The story they had to 
write was about a girl who was taken to the train station by a man and a woman, probably her relatives. But once she got onto the train, the ones who had driven her to the railway station noticed she had forgotten to carry her suitcase onto the train. So they got into their car and followed the train up to the next station and returned the suitcase to her.

\subsection{Task Conditions}

In this study, planning was operationalized at two levels: pre-task planning and online planning. The participants worked on the writing tasks in two classroom sessions. In the pre-task planning condition, the students were first given 10 minutes to think about what they wanted to write and to jot down any notes. The choice of planning time was based on Crookes (1989), Foster and Skehan (1996), and Wendel's (1997) studies. The teacher collected their notes before they started the writing task in which they were given 20 minutes to complete. According to Ellis and Yuan (2004), the reasons for this were that 'First, removing the notes ensured that the language elicited by all the participants was produced within the specified time limit. Second, the notes could be used as evidence regarding how individual students undertook the planning' (P. 70). In the online planning condition, based on Ellis and Yuan's (2004) study, the participants were not restricted in the amount of time they had for completing their writing task. They were told not to worry about any time limitations and could take as much time as needed.

\subsection{Retrospective interview}

Ten of the participants from the pre-task planning condition were randomly selected to take part in a retrospective interview after completing the writing task. The think-aloud procedure was not used in this investigation because time was one of our variables. In contrast, through the retrospective method one can identify the cognitive processes after the task completion. The data from the interview were used to see if there were any relationship between what the learners did while they planned for the writing composition and how they actually performed on the task. The participants in the pre-task planning condition were provided with 10 minutes time to plan their writing. They were allowed to take notes or jot down anything they wanted during this planning time. Then, prior to commencing the writing task their notes were collected. In the retrospective interview, the researchers provided the subjects with their notes. They were asked, using their notes as reminders to what they had done during the planning time, to explain what they were up to in the planning time slot. The subjects were asked to explicitly explain all the notes they had jotted down during the planning time prior to the execution of the actual task.

\subsection{Measurement of the variables}

Planning, which was the independent variable in this study, was estimated in terms of the amount of time that each participant took to complete the writing task. This measure is similar to the one Yuan and Ellis (2003) used to measure the independent variable in their study, namely planning.

Measures of accuracy, fluency, and complexity were developed to examine the participants' written production (Table 1). Following previous research, these measures were the same as 
those used in studies of oral production (e.g., Ahmadian \& Tavakoli, 2011; Foster \& Skehan, 1996; Wendel, 1997; Yuan \& Ellis, 2003). However, changes to the fluency measures were made to make them appropriate for written production. The fluency of the writings was measured according to the number of dysfluencies the total number of words a participant reformulated (crossed out and changed) divided by the total number of words produced. Complexity was measured based on the syntactic complexity of the written tasks the ratio of clauses to T-units in the participants' production. Accuracy measures were gathered in accordance to the number of error-free clauses the percentage of clauses that did not contain any errors. All errors in syntax, morphology, and lexical choice were considered. Lexical errors were defined as errors in lexical form or collocation.

Table 1. Variables.

\begin{tabular}{|l|l|l|}
\hline \multicolumn{1}{|c|}{ Variables } & \multicolumn{1}{|c|}{ Type of variable } & Measured \\
\hline Complexity & Dependent & Syntactic complexity \\
\hline Accuracy & Dependent & $\begin{array}{l}\text { Number of error free } \\
\text { clauses }\end{array}$ \\
\hline Fluency & Dependent & Number of dysfluencies \\
\hline $\begin{array}{l}\text { Planning time (Pre- } \\
\text { planning and Online } \\
\text { planning) }\end{array}$ & Independent & $\begin{array}{l}\text { Amount of time needed to } \\
\text { complete the writing task }\end{array}$ \\
\hline
\end{tabular}

In order to provide plausible answers to the research questions posed above, first, the planning time in the two conditions are compared. Then, independent sample t-tests are performed separately for the three dependent variables (CAF). Finally, the data obtained from the retrospective interviews are analyzed.

\section{Results}

As it was mentioned previously, the difference between the pre-task and online planning condition was that in the former the participants were given 10 minutes to plan, and 20 minutes to write the actual written narrative. Whereas in the latter the participants took as much time as they needed to complete the writing task without any time limitations. The table below shows the difference in the time spent on the writing task under the two planning conditions.

According to the t-test (table 2 and 3), the difference in the amount of time the two groups spent on the writing task was significant with the online group taking longer. The online planning group took longer to complete the task $(\mathrm{M}=31.00 \mathrm{~min}$. $)$ than those in the pre-task planning group ( $\mathrm{M}=20.00 \mathrm{~min}$.). 
Table 2. Group Statistics for planning time.

\begin{tabular}{|rl|r|r|r|r|}
\hline & & & & & \\
& Group & $\mathrm{N}$ & Mean & Std. Deviation & Std. Error Mean \\
\hline Planning & Pre-task & 20 & 20.0000 & .00000 & .00000 \\
& Online & 20 & 31.4000 & 3.93901 & .88079 \\
\hline
\end{tabular}

Table 3. Independent Samples Test for planning time.

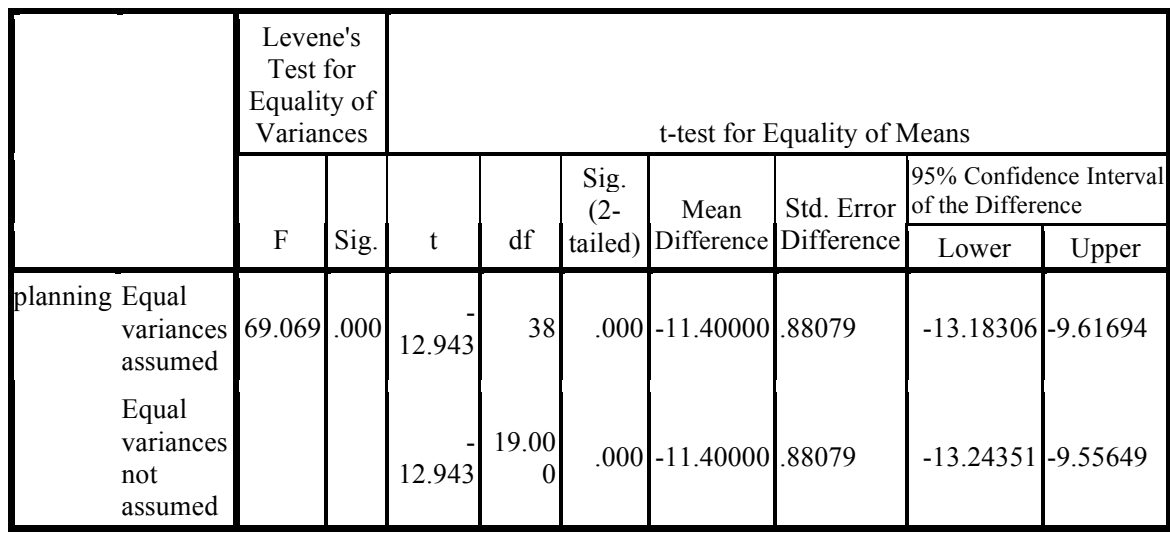

The writings of the participants were corrected by two raters based on the criterion available for measuring complexity, accuracy, and fluency. The inter-rater reliability was calculated based on Cronbach's alpha which was 0.89 for the compositions completed in the pre-task planning time and was 0.92 for the compositions completed in the online planning time conditions. This indicated that there was a positively high correlation among the two raters' decisions.

In order to answer the first three research questions, independent-samples t-tests were estimated and reported separately for complexity, accuracy, and fluency in the tables below.

Table 4 and 5 show the results for the accuracy variable. The online planning group obtained a higher mean $(\mathrm{M}=0.786)$. There was a significant difference between the two planning conditions in terms of accuracy, with the online planning group providing more error-free clauses. 
Table 4. Group Statistics for accuracy.

\begin{tabular}{|ll|r|r|r|r|}
\hline \multicolumn{2}{|c|}{ Planning } & $\mathrm{N}$ & \multicolumn{1}{c|}{ Mean } & Std. Deviation & Std. Error Mean \\
\hline \multirow{2}{*}{ Accuracy } & pre-task planning & 20 & .5355 & .15826 & .03539 \\
& online planning & 20 & .7860 & .10728 & .02399 \\
\hline
\end{tabular}

Table 5. Independent Samples Test for accuracy.

\begin{tabular}{|c|c|c|c|c|c|c|c|c|c|}
\hline & \multicolumn{2}{|c|}{$\begin{array}{c}\text { Levene's Test } \\
\text { for Equality } \\
\text { of Variances }\end{array}$} & \multicolumn{7}{|c|}{ t-test for Equality of Means } \\
\hline & \multirow[b]{2}{*}{$\mathrm{F}$} & \multirow[b]{2}{*}{ Sig. } & \multirow[b]{2}{*}{$\mathrm{t}$} & \multirow[b]{2}{*}{$\mathrm{df}$} & \multirow{2}{*}{$\begin{array}{c}\text { Sig. } \\
(2- \\
\text { tailed })\end{array}$} & \multirow{2}{*}{$\begin{array}{c}\text { Mean } \\
\text { Difference }\end{array}$} & \multirow{2}{*}{$\begin{array}{l}\text { Std. Error } \\
\text { Difference }\end{array}$} & \multicolumn{2}{|c|}{$\begin{array}{l}95 \% \text { Confidence } \\
\text { Interval of the } \\
\text { Difference }\end{array}$} \\
\hline & & & & & & & & Lower & Upper \\
\hline $\begin{aligned} & \text { Accuracy } \text { Equal } \\
& \text { variances } \\
& \text { assumed } \\
& \text { Equal } \\
& \text { variances } \\
& \text { not } \\
& \text { assumed }\end{aligned}$ & 1.391 & .246 & $\begin{array}{r}5.859 \\
\\
- \\
5.859\end{array}$ & 33.417 & .000 & $\begin{array}{l}-.25050 \\
-.25050\end{array}$ & .04275 & $\begin{array}{l}-.33705 \\
-.33744\end{array}$ & -.116395 \\
\hline
\end{tabular}

Tables 6 and 7 show the difference among the two planning conditions in relation to fluency. The total number of words reformulated by the pre-task planning group was more statistically significant than the online planning group. The results indicate that the preplanning group had a higher mean $(\mathrm{M}=0.1010)$ than the online planning group.

Table 6: Group Statistics for fluency.

\begin{tabular}{|ll|r|r|r|r|}
\hline \multicolumn{2}{|c|}{ Planning } & $\mathrm{N}$ & \multicolumn{1}{c|}{ Mean } & \multicolumn{1}{c|}{ Std. Deviation } & Std. Error Mean \\
\hline \multirow{2}{*}{ fluency } & pre-task planning & 20 & .1010 & .06052 & .01353 \\
& online planning & 20 & .0205 & .01050 & .00235 \\
\hline
\end{tabular}


Table 7. Independent Samples Test for fluency.

\begin{tabular}{|c|c|c|c|c|c|c|c|c|c|}
\hline & \multicolumn{2}{|c|}{$\begin{array}{l}\text { Levene's Test } \\
\text { for Equality of } \\
\text { Variances }\end{array}$} & \multicolumn{7}{|c|}{ t-test for Equality of Means } \\
\hline & \multirow[b]{2}{*}{$\mathrm{F}$} & \multirow[b]{2}{*}{ Sig. } & \multirow[b]{2}{*}{$\mathrm{t}$} & \multirow[b]{2}{*}{ df } & \multirow{2}{*}{$\begin{array}{c}\text { Sig. } \\
(2- \\
\text { tailed })\end{array}$} & \multirow{2}{*}{$\begin{array}{c}\text { Mean } \\
\text { Difference }\end{array}$} & \multirow{2}{*}{$\begin{array}{l}\text { Std. Error } \\
\text { Difference }\end{array}$} & \multicolumn{2}{|c|}{$\begin{array}{l}95 \% \text { Confidence } \\
\text { Interval of the } \\
\text { Difference }\end{array}$} \\
\hline & & & & & & & & Lower & Upper \\
\hline $\begin{array}{l}\text { Fluency Equal } \\
\text { variances } \\
\text { assumed } \\
\text { Equal } \\
\text { variances } \\
\text { not } \\
\text { assumed }\end{array}$ & 12.044 & .001 & $\begin{array}{c}5.861 \\
5.861\end{array}$ & 20.143 & .000 & .08050 & .01373 & .05270 & .10830 \\
\hline
\end{tabular}

Table 8 and 9below show the results for the complexity of the writing narratives produced by the two groups under the different planning conditions.

Table 8. Group Statistics for complexity.

\begin{tabular}{|ll|r|r|r|r|}
\hline \multicolumn{2}{|c|}{ planning } & \multicolumn{1}{|c|}{$\mathrm{N}$} & \multicolumn{1}{c|}{ Mean } & Std. Deviation & Std. Error Mean \\
\hline \multirow{2}{*}{ complexity } & pre-task planning & 20 & .7780 & .05317 & .01189 \\
& online planning & 20 & .5410 & .08372 & .01872 \\
\hline
\end{tabular}

Table 9. Independent Samples Test for complexity.

\begin{tabular}{|c|c|c|c|c|c|c|c|c|c|}
\hline & $\begin{array}{r}\text { Leve } \\
\text { Test } \\
\text { Equali } \\
\text { Varia }\end{array}$ & $\begin{array}{l}\text { ne's } \\
\text { for } \\
\text { ty of } \\
\text { aces }\end{array}$ & \multicolumn{7}{|c|}{ t-test for Equality of Means } \\
\hline & \multirow[b]{2}{*}{$\mathrm{F}$} & \multirow[b]{2}{*}{ Sig. } & \multirow[b]{2}{*}{$\mathrm{t}$} & \multirow[b]{2}{*}{ df } & \multirow{2}{*}{$\begin{array}{c}\text { Sig. } \\
(2- \\
\text { tailed })\end{array}$} & \multirow{2}{*}{$\begin{array}{c}\text { Mean } \\
\text { Difference }\end{array}$} & \multirow{2}{*}{$\begin{array}{l}\text { Std. Error } \\
\text { Difference }\end{array}$} & \multicolumn{2}{|c|}{$\begin{array}{l}95 \% \\
\text { Confidence } \\
\text { Interval of th } \\
\text { Difference }\end{array}$} \\
\hline & & & & & & & & Lower & Upper \\
\hline $\begin{array}{l}\text { Complexity Equal } \\
\text { variances } \\
\text { assumed } \\
\text { Equal } \\
\text { variances } \\
\text { not } \\
\text { assumed }\end{array}$ & 3.073 & .088 & $\begin{array}{l}10.687 \\
10.687\end{array}$ & $\begin{array}{r}38 \\
32.183\end{array}$ & .000 & $\begin{array}{l}.23700 \\
.23700\end{array}$ & .02218 & $\begin{array}{l}.19210 \\
.19184\end{array}$ & $\begin{array}{l}.28190 \\
.28216\end{array}$ \\
\hline
\end{tabular}


In this study syntactic variety was measured to assess the complexity of the language produced in the written narratives. Overall, the differences among the two groups were statistically significant in that the pre-task planning group produced more clauses. These results indicated that the opportunity for pre-task planning resulted in more fluent and complex written production. Whereas the online planning group outperformed the other group in terms of the number of error free clauses produced.

The data obtained from the interviews revealed how the subjects in the pre-task planning condition managed their time prior to the actual writing performance. All of them had started by looking at the pictures and trying to figure out what had happened in the story. The majority of the subjects reported that they started out by telling the story to themselves in Persian (L1). Then most of them had planned the L2 vocabulary they wanted to use in the writing task. Most of the subjects mentioned that they tried to think of a way to make the story more interesting; thinking of what pictures might have come before and after the selected pictures of the task. All of them had jotted down some linking words to use in going from one picture to the other. This showed us how the pre-task planning group organized their planning time.

\section{Discussion}

This study was primarily aimed at examining the effects of pre-task and online planning conditions on complexity, accuracy, and fluency in EFL learners' written production. In this section we will summarize the findings of the study and discuss our findings in relation to other studies.

It was shown in the results section that the participants in the online planning group spent more time on task completion than those in the pre-task planning group. Therefore, it could be argued that careful online planning has been successfully operationalized. Regarding the first research question posed, examining the effect of pre-task and online planning on accuracy, it was found that the participants in the online planning group outperformed the pre-task planning group in the number of error-free clauses produced. In a way, this finding is consistent with the results that Hulstijn and Hulstijn (1984), Ellis (1987), and Yuan and Ellis (2003) obtained. These three studies suggest that the time learners are given for online planning improves the accuracy of their production. Our finding lends support to Skehan's (1998) dual-mode system proposal. Skehan states that rule-based system is likely to be 'parsimoniously and elegantly organized, with rules being compactly structured' (p. 89). In order to be accessed the performers of tasks need more time and attention. Therefore, when learners are given as much time as needed and are not pressured for time they may draw on their rule-based system. Making use of this rule-based system in oral production explains higher level of accuracy (Ahmadian \& Tavakoli, 2011).

In terms of the second research question the results of the present study indicate that pre-task planning positively affects fluency. In pre-task planning the participants are given time prior to the writing performance. During this time the participants in most cases try to understand the story illustrated in the pictures, organize the information that needs to be conveyed, establish the setting and describe the characters without feeling any pressure. In line with our findings, a number of studies have confirmed that giving learners the opportunity 
to plan results in greater fluency (e.g., Foster \& Skehan, 1996; Skehan \& Foster, 1997; Wigglesworth, 1997; Wendel, 1997; Mehnert, 1998; Ortega, 1999).

Pre-task planning also has some effect on complexity. The pre-task planners used more syntactic complexity in their written narratives. Our finding regarding complexity is in a way in line with Wendel's (1997) claim and Yuan and Ellis's (2003) finding that complexity in language production is closely linked with pre-task planning.

In summary, pre-task planning has a marked effect on written fluency, a relatively strong effect on linguistic complexity; whereas online planning has an effective impact on accuracy. According to Ellis and Yuan (2004: 81) it is clear that pre-task planning enhances learner output in a written task. 'This is manifested in greater quantity, fluency, and complexity of language, although such planning appears to have little effect on accuracy'.

\section{Conclusion}

The purpose of this article was to explore the effects of two types of planning (pretask and online) on textual output. Although there have been studies investigating what L1 writers do during planning, few have focused on the effects of planning on L2 writing performance (Ellis \& Yuan, 2004). This study, being in line with Ellis and Yuan's (2004) study, suggests that pre-task planning has a positive effect on the fluency and complexity of the written output, whereas online planning has an influential impact on the accuracy of the written product.

This has important implications for writing pedagogy. Depending on the purpose of writing tasks teachers assign EFL learners, different aspects of the writing performance can be emphasized by altering the type of planning conditions.

\section{Aknowledgment}

The authors are grateful to the participants of the study and the anonymous reviewer(s) for their constructive comments.

\section{REFERENCES}

Ahmadian J. and Tavakoli, M. (2011). The effects of simultaneous use of careful online planning and task repetition on accuracy, complexity and fluency in EFL learners' oral production, in Language Teaching Research, 15, 1: 35-59.

Crookes, G. (1989). Planning and interlanguage variation, in Studies in Second Language Acquisition, 11: 367383.

Ellis, R. (1987). Interlanguage variability in narrative discourse: Style in the use of the past tense, in Studies in Second Language Acquisition, 9: 12-20.

Ellis, R. (Eds.). (2005). Planning and Task Performance in a Second Language. John Benjamins.

Ellis, R. (2008). The Study of Second Language Acquisition.2nd ed. Oxford: Oxford University Press. 
Ellis, R. and Barkhuizen, G. (2005). Analyzing Learner Language. Oxford: Oxford University Press.

Ellis, R. and Yuan, F. (2004). The effects of planning on fluency, complexity, and accuracy in second language narrative writing, in Studies in Second Language Acquisition, 26: 59-84.

Foster, P. and Skehan, P. (1996). The influence of planning on performance in task-based learning, in Studies in Second Language Acquisition, 18, 3: 299-324.

Hulstijn, J. andHulstijn, W. (1984). Grammatical errors as a function of processing constraints and explicit knowledge, in Language Learning, 34: 23-43.

Kroll, B. (1990). What does time buy? ESL student performance on home versus class compositions, in B. Kroll (Ed.), Second language writing. New York: Cambridge University Press, $140-154$.

Mehnert, U. (1998). The effects of different lengths of time for planning on second language performance, in Studies in Second Language Acquisition, 20: 52-83.

Ortega, L. (1999). Planning and focus on form in oral performance, in Studies in Second Language Acquisition, 21: 108-148.

Skehan, P. (1996). Second-language acquisition research and task-based instruction, in J. Willis and D. Willis (Eds.): Challenge and Change in Language Teaching. Oxford: Heinemann, $17-30$.

Skehan, P. (1998). A Cognitive Approach to Language Learning. Oxford: Oxford University Press.

Skehan, P. (2009). Modeling second language performance: Integrating complexity, accuracy, fluency, and lexis, in Applied Linguistics, 30, 3: 510-532.

Skehan, P. and Foster, P. (1997). Task-type and task processing conditions as influences on foreign language performance, in Language Teaching Research, 1, 3: 1-27.

Wendel, J. (1997). Planning and second language narrative production. Unpublished doctoral dissertation. Tokyo: Temple University Japan.

Wigglesworth, G. (1997). An investigation of planning time and proficiency level on oral test discourse, in Language Testing, 14: 85-106.

Yuan, F. and Ellis, R. (2003). The effects of pre-task planning and on-line planning on fluency, complexity and accuracy in L2 oral production, in Applied Linguistics, 24: 127. 